\title{
Non-marine algae of Australia: 3. Audouinella and Balbiania (Rhodophyta)
}

\author{
Stephen Skinner and Timothy J. Entwisle
}

\begin{abstract}
Skinner, S. and Entwisle, T.J. (Royal Botanic Gardens Sydney, Mrs Macquaries Road, Sydney NSW 2000, Australia) 2001. Non-marine algae of Australia: 3. Audouinella and Balbiania (Rhodophyta). Telopea 9(3): 713-723. Four species of freshwater, uniseriate red algae (Rhodophyta) from Australia are documented and distinguished, and their distribution in New South Wales outlined. The occurrence of Audouinella hermannii in NSW has been confirmed, and its range extended, while A. eugenea, previously reported from Queensland, is shown to be quite widespread in northern NSW and Lord Howe Island. A new species, A. scopulata, is described from creeks in the sandstone area around Sydney. The endophyte of Batrachospermales, Balbiania investiens, is reported in detail for the first time from the Australian region.
\end{abstract}

\section{Introduction}

The freshwater members of the genus Audouinella are common but infrequently collected cushion-like red algae found free living or as epiphytes on other vegetation in small but permanent waterways in most parts of the world. Records in Australia have been infrequent in the past (Entwisle 1989; Entwisle \& Kraft 1984), perhaps because of a greater interest by collectors in the algae of still-water areas, like lagoons, swamps and dams. Recent collections in the highlands of New South Wales and the Hawkesbury Sandstone area have demonstrated the presence of at least three species in that state, one of which is new to science.

An endophyte referable to Balbiania, has been noted in a number of samples from Australia, but rarely reported in the literature. Gunning et al. (1987) and Entwisle (1989) report the genus as an endophyte of Batrachospermum, Nothocladus and Sirodotia, but without description.

\section{Materials and methods}

Wet material was preserved initially in 5\% commercial formalin, later replaced with $70 \%$ alcohol (with 5\% glycerol). Microscope preparations were stained with aniline blue, toluidine blue or Lugol's Iodine before mounting in 'Karo' (10\% replaced with 40\%). Herbarium abbreviations follow Holmgren et al. (1981).

This research was funded through the NSW Biodiversity Strategy

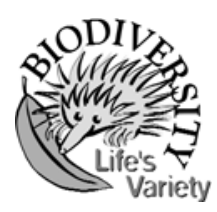


Determination of appropriate nomenclature has been made by comparison with recent published revisions for the taxa rather than comparison with type material, as the difficulties outlined in Skinner and Entwisle (2001a) apply in this case as well.

\section{Taxonomy}

\section{Acrochaetiaceae}

\section{Audouinella Bory}

A genus of both marine and freshwater Rhodophyta, with many marine taxa and a small but widespread group of freshwater taxa, including the Type species, A. hermannii (Roth) Duby. In Australia three or four freshwater taxa are recorded from Queensland, New South Wales, Victoria and South Australia (Entwisle 1994), with most records being of A. hermannii, and the description in Entwisle and Kraft (1984) is sufficiently broad to encompass all taxa discussed below. Members of this genus have been revised recently (Necchi et al. 1993a, 1993b; Necchi \& Zucchi 1995).

\section{Key to the species in New South Wales}

1 Lateral branches produced more or less evenly throughout the tuft; branch angle frequently between $20-30^{\circ}$ to main axis; monosporangia on several times branched short lateral (fasciculated) systems with central axis A. hermannii

$1^{*}$ Lateral branches most frequent in upper parts of tuft; branch angle frequently $15^{\circ}$ or less; monosporangia not as above

2 Rhizoidal system unspecialised; monosporangia large (c. $15 \mu \mathrm{m}$ in diameter) and spherical on well developed, sometimes palmate, short laterals

A. eugenea

$2^{*}$ Rhizoidal system ropey and plait-like; monosporangia ellipsoid, c. $10 \mu \mathrm{m}$ in diameter, on onecelled pedicel or sessile A. scopulata

Audouinella hermannii (Roth) Duby in DC., Bot. Gal. 2: 972 (1830).

Conferva hermannii Roth, Cat. Bot. 3: 180 (1806).

Plants macroscopic, to $15 \mathrm{~mm}$ high, and composed of numerous uniseriate filaments, reddish. Basal system a prostrate open system on host or rock; erect system muchbranched filaments with laterals forming at angles of $20-30^{\circ}$ to the main axis; branching by laterals of indeterminate length throughout the tuft, so whole having a dendroid appearance; rhizoidal filaments little different from erect axes, except cells more undulate and slightly thicker walled; vegetative cells of erect filaments cylindrical, thick walled, (18-)30-55(-80) $\mu \mathrm{m}$ long, (6-)9-10(-15) $\mu \mathrm{m}$ diam., terminal cell domed, parietal plastid a reticulate system of irregular discoid fragments; hairs, when present, one-celled, terminal on lateral branches, narrow, 60-120 $\mu \mathrm{m}$ long, 2-2.5 $\mu \mathrm{m}$ wide. Monosporangia carried on short, oppositely branching laterals, in which the main axis may have 4 or 5 cells, the lower 2 often without laterals, and the side axes developing on upper 1 or 2 cells; monosporangia develop in groups of two or three, fresh spores developing inside old sporangium wall; ovoid to ellipsoid, 9-12(-14) $\mu \mathrm{m}$ long, 6-10(-11) $\mu \mathrm{m}$ diam. Sexual structures not seen in New South Wales collections. (Fig. 1d).

Distribution \& habitat: Found as coatings on rocks, and occasionally bryophytes (when the mass of tufts look like bunches of currants), or the blades of submerged aquatic macrophytes, in fast flowing, cold, clear mountain streams. Apparently widespread in eastern mainland Australia with previous published records from 
Victoria and South Australia (Entwisle \& Nairn, 1999). Only New South Wales and Queensland specimens, held at NSW, examined on this occasion.

Notes: The New South Wales material cited above has a general morphology similar to Brazilian material described by Necchi and Zucchi (1995), and the dimensions similar to both the type and the North American material of Necchi et al. (1993a). Harper and Saunders (1998) using a Victorian collection comparable with the New South Wales material and sequenced by Vis et al. (1998), showed $100 \%$ complementarity in rbcL gene sequences between Australian and North American material. No sexual or tetrasporic material was observed in New South Wales material. A Queensland population (Entwisle 2982) showed sexual stages comparable with those described by Drew (1935).

Specimens examined: Queensland: Nixons Ck, between Nagarigoan Falls and Ballanjui Cascade, Binna Burra area, Lamington National Park, Entwisle 2983, 17 Jul 1999 (NSW).

New South Wales: Southern Tablelands: Jacobs (Tongaroo) River, near confluence with Snowy River, N.G.Walsh s.n., Jan 1994, (MEL); Pipers Ck, Jindabyne-Mt Koscius[z]ko road, Entwisle 1571, 11 Nov 1988, (MEL); Leather Barrel Ck, Alpine Way, Entwisle 1578, 12 Nov 1988, (MEL); Thredbo River, near Jindabyne, Entwisle 1577, 12 Nov 1988, (MEL); Bradneys Gap Rest Area, 12 km N of Khancoban, B. Archer 505, 23 Dec 1996, (MEL);

Audouinella eugenea (Skuja) Jao, Sinensia 10: 362 (1940).

Chantransia eugenea Skuja, Beih. Bot. Centralb. 52: 177 (1934).

Plants macroscopic, pulvinate, 5-7 mm high, composed of numerous uniseriate branching filaments from a compact rhizoidal base, dark reddish, frequently on aquatic mosses. Erect system much branched throughout, laterals forming at angles of $15-20(-25)^{\circ}$ to the main axis but curving back to be more or less parallel; rhizoidal filaments thick walled and undulate; vegetative cells of erect axes cylindrical, thick walled, (20-)30-60 $\mu \mathrm{m}$ long and 10-12 $\mu \mathrm{m}$ diam., terminal cell long and domed, plastids parietal, densely reticulate; hairs absent in specimens examined. Monosporangia carried on palmate short lateral branches of closely appressed subdeltoid cells, branching mostly away from the axis; monosporangia subglobose, 14-16 $\mu \mathrm{m}$ long, 14-15 $\mu \mathrm{m}$ diam., mother-cell wall persistent. (Fig. $1 \mathrm{a}-\mathrm{c}$ ).

Distribution \& habitat: found as tufts, sometimes crowded, so looking like clusters of berries, on aquatic vegetation in New South Wales. Recorded from a coastal cavern in Queensland (Cribb 1965), and from Asia and both North and South America (Carmona and Necchi 2001).

Notes: The main distinctions between this taxon and A. hermannii are in the form of the sporangial branches and the size of the monosporangia. The short laterals in A. hermannii have a distinct candelabra-like form, sometimes described as fasciculate, separate, cylindrical (at least in the lower parts) cells and ellipsoid spores, 9-12(-14) $\mu \mathrm{m}$ long, 6-10(-11) $\mu \mathrm{m}$ diam. A. eugenea has a close packed short lateral branch, subdeltoid cells and subspherical spores14-16 $\mu \mathrm{m}$ long, 14-15 $\mu \mathrm{m}$ diam. A less reliable distinction can be made by comparing the manner of the longer laterals: the angle with the main axis is generally narrower than for A. hermannii, $\left(15-20^{\circ}\right.$ cf. $\left.20-30^{\circ}\right)$ and there is a tendency for the laterals to grow parallel with the main axis, giving some appearance of fasciculation, though not as marked as in the following species.

Australian material agrees in dimensions with Jao (1941) although the subglobose form of monosporangium is distinctive and these are produced on both sides of the branches. It also corresponds to Skuja (1934) and Cribb (1965), except where the monosporangial laterals show greater development (Fig. 1c).

A collection of Audouinella from the Brunswick River in northern N.S.W. (Entwisle 2979) was found among the rhizoids at the base of Batrachospermum antipodites and 


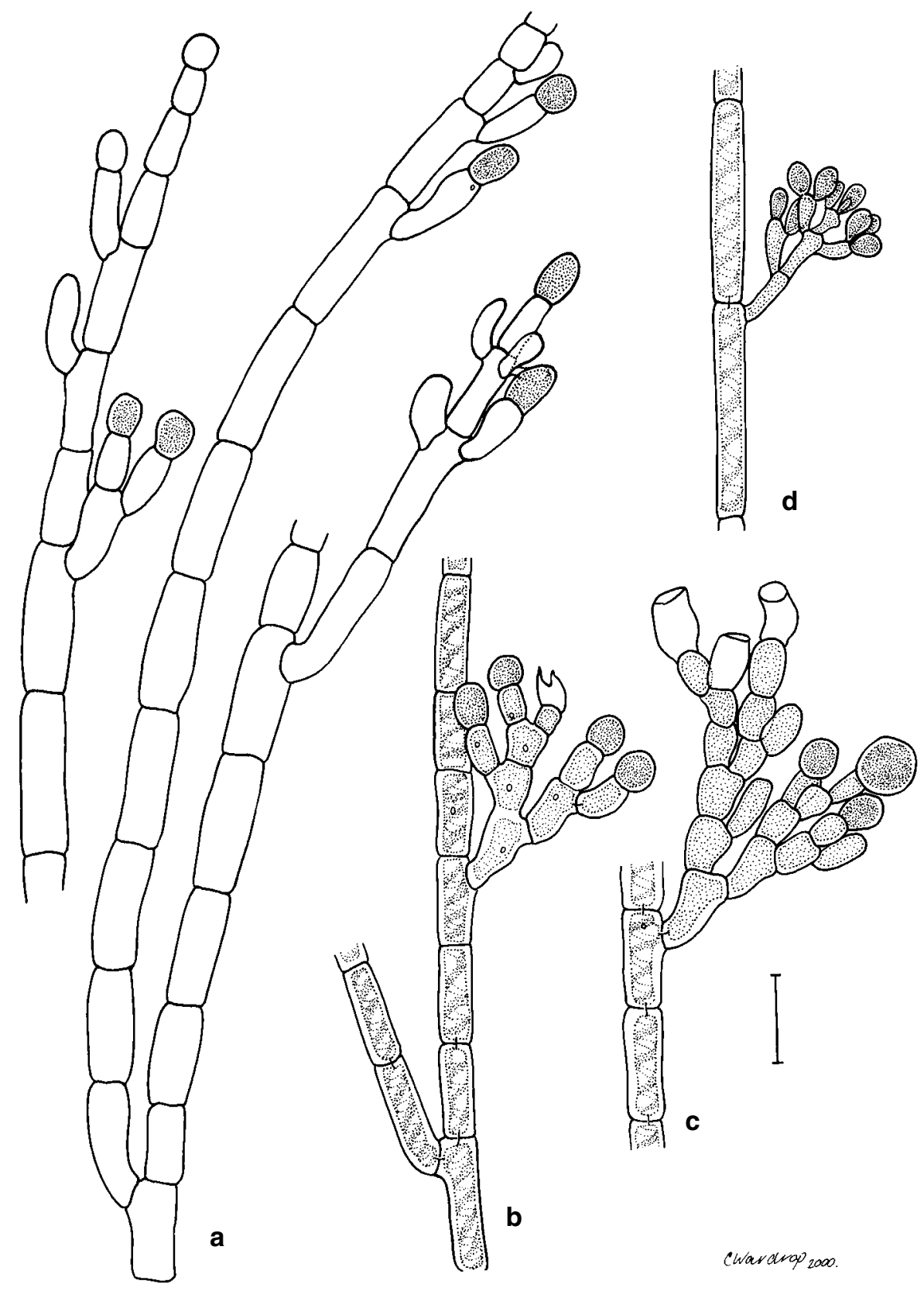

Fig. 1. Audouinella: a-c Audouinella eugenea, a, erect axis, showing narrow branch angle, and scattered monosporangial laterals; b, c, palmate monosporangial laterals (Skinner 0203); d, Audouinella hermannii, monosporangial lateral (B. Archer 505). Scale bar $=25 \mu \mathrm{m}$. 
may perhaps be its 'chantransia' (or sporophyte) phase. Some axes of this specimen had sections of short, broadly deltoid cells in the upper parts which supported alternate lateral branches. Monosporangia similar to those of $A$. eugenea were present on long-celled axes. One fragment showed two audouinelloid axes and a new Batrachospermum axis apparently arising from the same filament.

Specimens Examined: New South Wales: Central Western Slopes: Guntawang Bridge, Cudgegong River, 8 km from Gulgong, Entwisle 2883, 17 Jul 1997 (MEL). Northern Tablelands: MacDonald River, Bendemeer, Skinner 0070, 21 May 2000 (NSW); Apsley Falls, Apsley River, 20 km east of Walcha, Skinner 0203, 25 May 2000 (NSW). North Coast: Boat Harbour, Lord Howe Island, Conn 4362, 4367, Brown \& Downs, 16 Nov 2000 (NSW).

\section{Audouinella scopulata Skinner E Entwisle sp. nov.}

Thallus pulvinatus ad $5 \mathrm{~mm}$ altus, systematice rhizoidali intertexto funiculare, axibus erectis longis atque ramulis lateralibus in fasciculis scopulatiformibus supra formantibus; ramuli laterales ad axem fere paralleli (ad angulam 15-20 ); monosporangia aut sessilia aut breviter pedicellata in axibus supernis singularibus ovoideisque, $12-15 \mu \mathrm{m} \times 8-10 \mu \mathrm{m}$; monoecius: spermatia in ramulis lateralibus brevibus, trichogyna itidem in ramulis similibus frequentiter apicem versus, ramulis carpogonialibus furcatis; carpogonia monosporiis similia saepe in ramulo secunda.

Holotype: McCarrs Creek, near Duckholes Picnic Area, Ku-Ring-Gai Chase National Park, Entwisle 2929, 3 Jan 1999 (NSW).

Plants macroscopic, 7-10 mm high, composed of numerous uniseriate erect filaments and a compact basal system of rhizoids, reddish. Basal system a complex mat of interwoven rhizoidal filaments, or a disc of squat many-sided cells; erect system of much-branched uniseriate filaments, with short and long laterals developing at very acute angles to the main axis, so that erect branches are all parallel; branching concentrated in upper two-thirds of tuft, most laterals reaching the same level, giving a broom-like appearance to axes; rhizoidal cells in the interwoven parts undulate, (15-)35-50 $\mu \mathrm{m}$ long, 10-12(-20) $\mu \mathrm{m}$ diam., contents pigmented, arising from lower cells of erect axes, leading cell terminally rounded; cells in adjacent rhizoidal filaments may anastomose and broaden so as to form a disc-like basal system; vegetative cells of main branches (25-)45-55 $\mu \mathrm{m}$ long, (12-)15-18 $\mu \mathrm{m}$ diam., thick-walled, plastids parietal, reticulate, cells narrowing slightly above, terminal cell rounded; hairs, when present, long, with bulbous base, terminal on lateral branches. Monoecious. Spermatangia on short laterals, of 1 or 2 cells supporting subdeltoid cells with 2 or 3 ellipsoid or pyriform small cells with spermatial packets on top; trichogyne 25-35 $\mu \mathrm{m}$ long on a short lateral branch towards tip of a vegetative filament often with spermatangia on adjacent cells. Following fertilization, the carpogonial branch becoming candelabra-like and covered, often on one side only, with ellipsoid carpospores, similar in shape to monosporangia, 15-18 $\mu \mathrm{m}$ long, 12-15 $\mu \mathrm{m}$ diam. Monosporangia developed in the upper, thickly branched parts of axes, either on a single-celled lateral or terminal pedicel, or a 2 or 3 celled lateral, which branches once (or twice), or sessile on the top 2 or 3 cells of a filament, and occurring singly, 12-15(-18) $\mu \mathrm{m}$ long, (7-)8-12(-15) $\mu \mathrm{m}$ diam. (Figs 2 \& 3)

Etymology: The specific epithet scopulata is derived from the latin (scopae) for a broom made of twigs, a besom, which the bundles of laterals on main axes resemble.

Distribution and habitat: found on rocks and bryophytes in warm temperature streams, either as tufts in sluggish water or as a reddish black felt several centimetres across in the splash zone of waterfalls or in seepages. Only recorded from the Blue Mountains and Sydney Sandstone areas of New South Wales. 


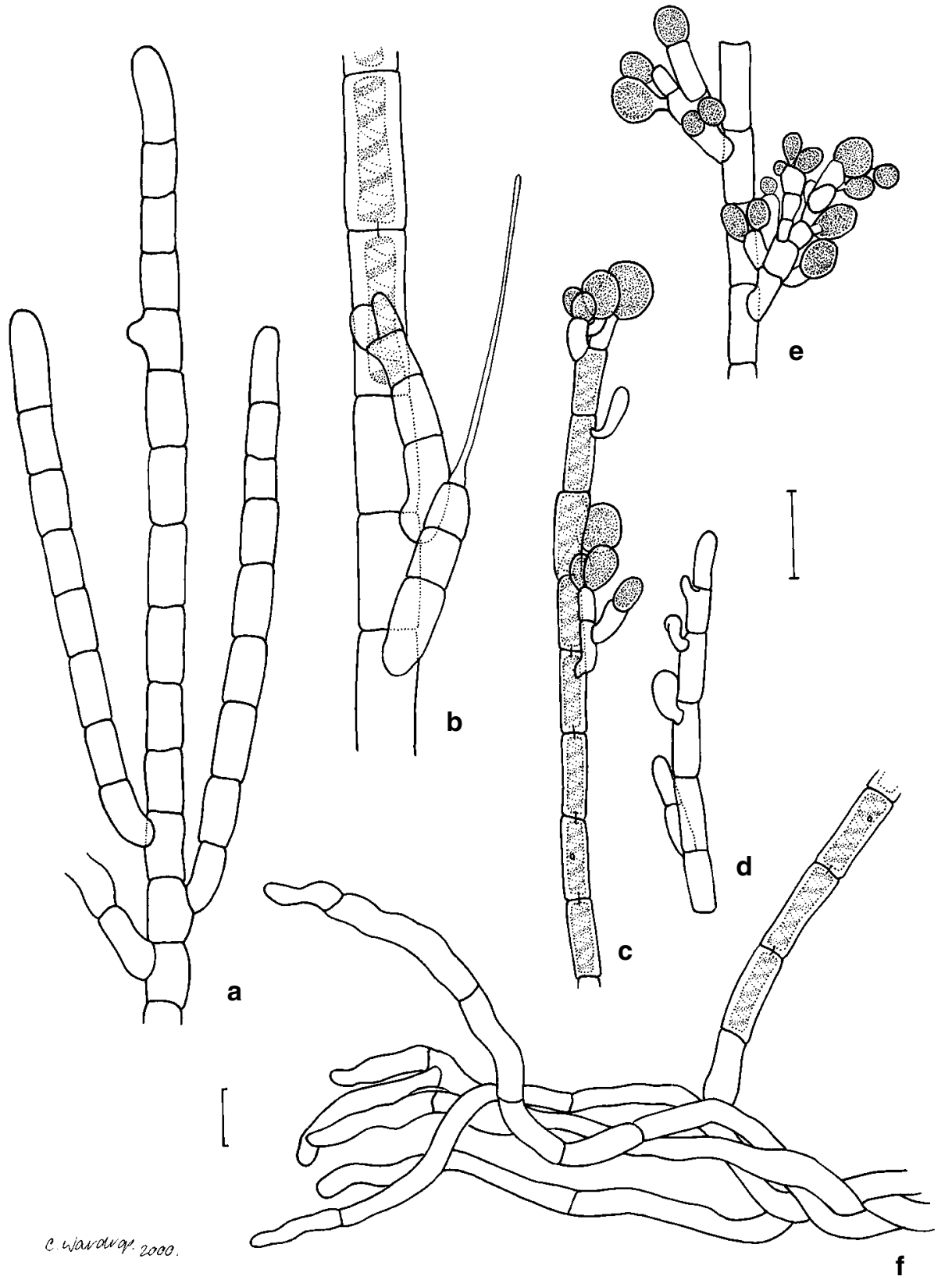

Fig. 2. Audouinella: a-f Audouinella scopulata, a, tip of erect axis; $\mathbf{b}$, lateral branch with hair; c-e, monosporangial laterals in various stages of development; $f$, intertwining rhizoidal system (Entwisle 2929). Scale bars: $\mathrm{a}-\mathrm{e}=25 \mu \mathrm{m} ; \mathrm{f}=25 \mu \mathrm{m}$. 


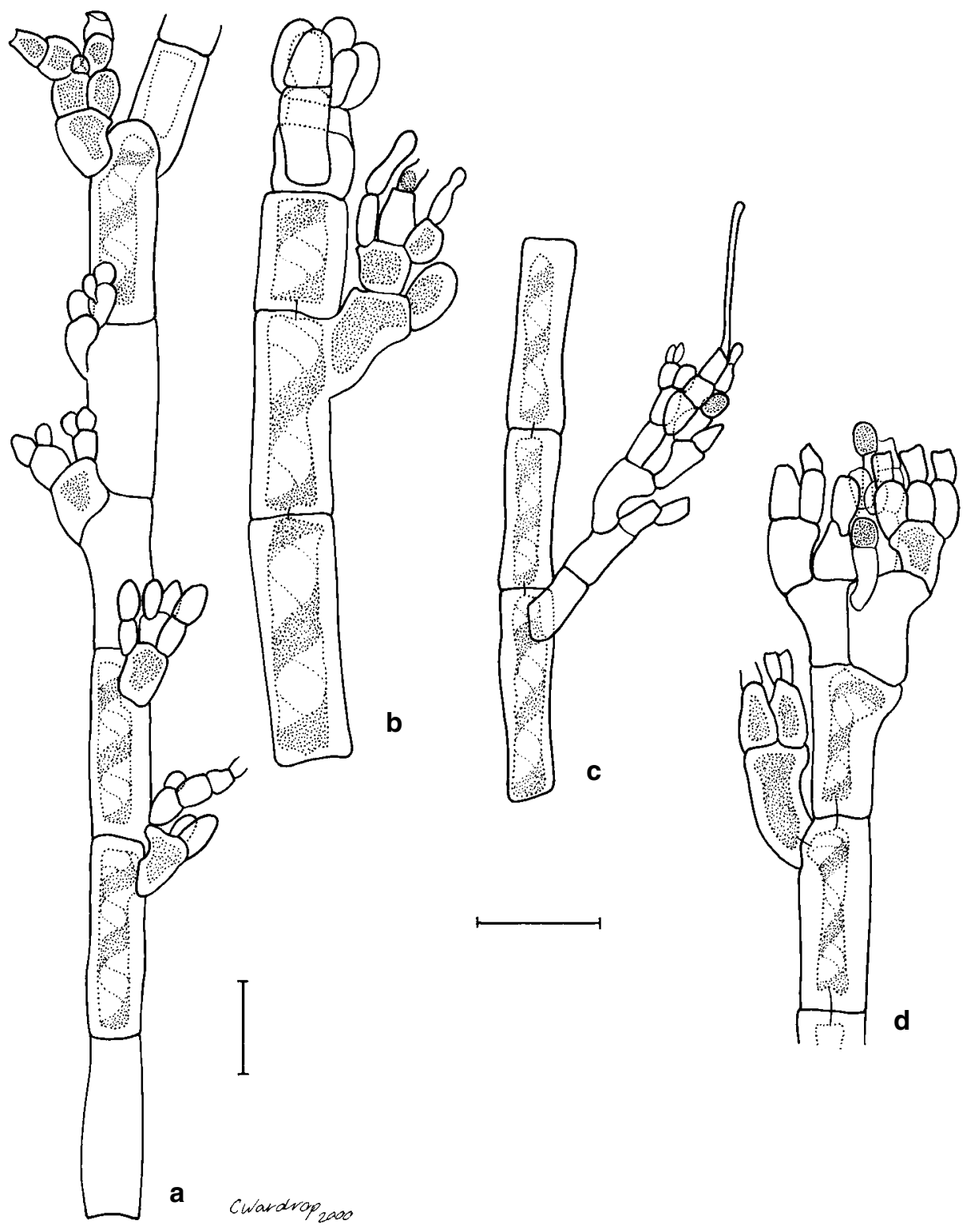

Fig. 3. Audouinella: a-d A. scopulata, a, spermatangial laterals; b, developing trichogynes; c, mature trichogyne; d, carpogonial branch (Entwisle 2929). Scale bars: $a=25 \mu \mathrm{m} ; b-d=25 \mu \mathrm{m}$. 
Notes: Where abrasion or grazing damage has occurred two forms of regrowth are observed. The top cell may give rise to two new cells that may develop as short branches with reproductive structures. Alternatively the new top cell may be a hair initial, which is quickly broken, and new upward growth may come from the cells immediately below the top cell.

The branch angle displayed by our material is similar to that for A. tenella (Skuja) Papenfuss, and distinctly different from that of $A$. hermannii. The vegetative cells of $A$. scopulata are much thicker than A. tenella (12-15 $\mu \mathrm{m}$ cf. 4-6 $\mu \mathrm{m}$; see Necchi and Zucchi 1995), and tetrasporic material has yet to be found. The process of sexual reproduction appears to be similar to the pattern described for Audouinella hermannii (as Rhodochorton violaceum) by Drew (1935) and Necchi et al. (1993a).

Specimens Examined: New South Wales: Central Tablelands: Jenolan Caves, Jenolan River near Oberon, Entwisle 1918, 7 Feb 1991 (MEL). Central Coast: Gordon Ck, Killara, Entwisle 2475, 15 Nov 1995 (MEL); Creek into Lovett Bay, West Head Road, Ku-Ring-Gai Chase Nat. Pk, Entwisle 2927 3 Jan 1999 (NSW); McCarrs Ck near Duckholes Picnic Area, Ku-ring-gai Chase Nat. Pk, Entwisle 2928, 3 Jan 1999, (NSW), Entwisle 3042, 3043, 3045, 5 Aug 2000 (NSW).

\section{Balbianiaceae}

The Balbianiaceae, and the Balbianiales, were established recently by Sheath and Müller (1999) to include Balbiania and Rhododraparnaldia, on the basis of specialised reproductive structures (spermatangial branches) and DNA sequence data.

\section{Balbiania Sirodot}

A genus with previously two species, B. investiens (Lenormond) Sirodot from Europe, and B. meiospora Skuja from New Zealand. Balbiania is an endophyte, and while both species have been placed in Audouinella at one time or another, most recent work (Leukart \& Knappe 1995; Sheath \& Müller 1999; Carmona \& Necchi 2001) suggests this is a distinct genus, more closely related to Rhododraparnaldia. Balbiania meiospora has been removed to Audouinella once again, as it does not develop the specialized spermatangia characteristic of the genus.

Balbiania investiens (Lenorm.) Sirodot, Ann. Sci. nat. Bot., Sér. 6, III : 149 (1876).

Chantransia investiens Lenorm. in Kützing, Species algarum: 431 (1849).

Endophytic, rhizoidal thalli, growing among the cortex of species of Batrachospermales. Rhizoids extensive and interweaving, mostly of fusiform cells with occasional larger, irregular to balloon shaped cells close fitting among the cortical host cells; erect processes uniseriate, arising either from the upper corners of balloon cells or sub-terminally from the fusiform cells, of 2 or 3 obpyriform cells, often forking and with the terminal cell(s) clavate to ellipsoid, shorter, with a long seta; axial initials along the stoloniferous rhizoidal processes clavate. Monosporangia scattered throughout the thallus, lateral to inflated cells, or terminal, subtended by one of a pair of cells on a subterminal inflated cell, clavate to subglobose, 6.0-7.5 $\mu \mathrm{m}$ long, (4.5-)5.5-6.0 $\mu \mathrm{m}$ diam. No definite sexual structures observed. (Fig. 4).

Distribution and habitat: endophytic in species of Batrachospermales growing in fast flowing streams, also recorded from Europe and North America.

Notes: Our Australian specimens have distinctive elongate obpyriform cells in their short erect filaments, rather than the cylindrical ones of $B$. investiens as illustrated by Leukart and Knappe (1995) and Sheath and Müller (1999). The Australian material has not been found with sexual stages, but has plenty of monosporangia, which are more inflated than those illustrated by Leukart and Knappe (1995) and only paired in the 


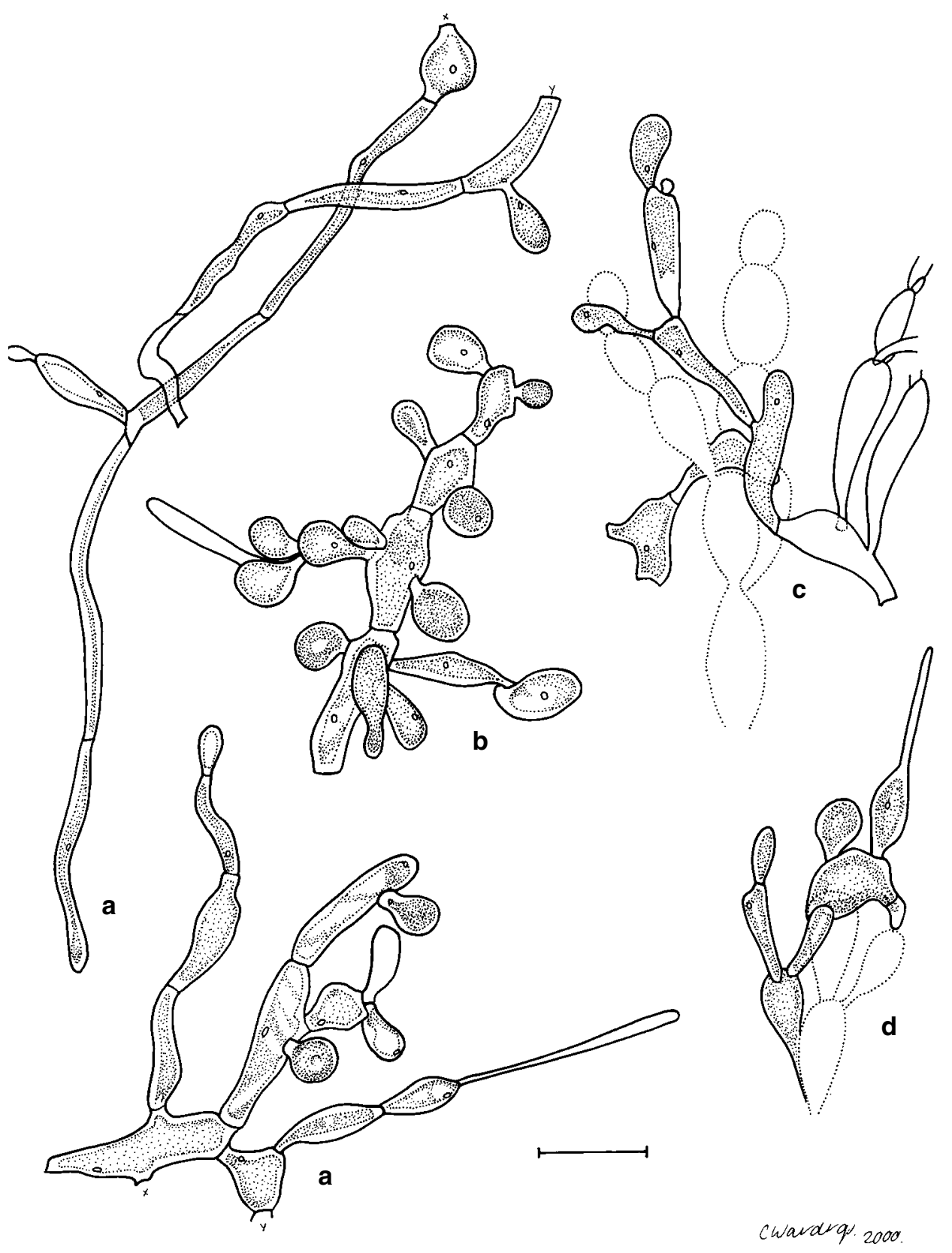

Fig. 4. Balbiania: a-d Balbiania investiens, a, endophytic filaments; b, endophytic axis with numerous monosporangia; $\mathbf{c}, \mathbf{d}$, erect processes among outer cortex of host (Batrachospermum $\mathrm{sp}$.) (Skinner 0143). Scale bar $=10 \mu \mathrm{m}$. 
manner described above when terminal to erect filaments, not opposite along filaments as in Sheath and Müller (1999). Australian material is also finer in dimensions than that described by Leukart and Knappe (1995). However, until more collections become available, and since we recognise the plasticity of endophytic organisms, it seems best to retain this form within $B$. investiens.

Endophytic red algae have been noted by the second author on collections of other algae in the past, e.g. collections of Batrachospermum wattsii from Wilsons Promontory, Nothocladus spp. and Sirodotia sp. from the Yarra River, and Batrachospermum theaquum from Barren Grounds Nature Reserve and elsewhere. They may represent further records of this species, and a broader survey is warranted. As the worldwide dispersal of Balbiania raises some interesting biogeographical questions, it would be most interesting to establish the phylogenetic relationship of this taxon.

Specimens Examined: New South Wales: North Coast: bridge over Little Murray River, Waterfall Way, c. 6 km W of Dorrigo, in Batrachospermum sp. aff. theaquum, Skinner 0143, 24 May 2000 (NSW).

Victoria: Little Yarra River, Yarra Junction, c. 9 km SW of Warburton, in Batrachospermum wattsii, Entwisle 3103, 29 Dec 2000 (NSW).

\section{Acknowledgments}

Thanks are due to Catherine Wardrop for the completion of the illustrations, to Wayne Cherry, Barry Conn, Elizabeth Brown and Katherine Downs (Royal Botanic Gardens Sydney) for collections and MEL for loan of specimens. This work was supported by a grant from NSW National Parks \& Wildlife Service through the New South Wales Biodiversity Strategy.

\section{References}

Carmona, J.J. \& Necchi, O. Jr. (2001) A new species and expanded descriptions of Audouinella (Acrochaetaceae, Rhodophyta) from Central Mexico and southeastern Brazil. E. J. Phycol. 36: 217-226.

Cribb, A.B. (1965) An ecological and taxonomic account of the algae of a semi-marine cavern, Paradise Cave, Queensland. Papers Dept Bot. Univ. Queensland 4(16): 259-282.

Drew, K.M. (1935) The Life-history of Rhodochroton violaceum (Kütz.) comb. nov. (Chantransia violacea Kütz.). Ann. Bot. 49: 439-450.

Entwisle, T.J. (1989) Macroalgae in the Yarra River basin: flora and distribution. Proc. Roy. Soc. Vic. 101: 1-76.

Entwisle, T.J. (1994) (ed.) Aquatic Cryptogams of Australia. Australian Society for Limnology. Special Publication No. 10. Victoria.

Entwisle, T.J. and Kraft, G.T. Survey of Freshwater Red Algae (Rhodophyta) of South-eastern Australia. Aust. J. Mar. Freshw. Res. 35: 213-259.

Entwisle, T.J. \& Nairn, L. (1999). Freshwater Algae - Census of Freshwater Algae in Australia (version 1). http://plantnet.rbgsyd.gov.au/PlantNet/fwalgae/index.htm

Fritsch, F.E. (1935) The Structure and Reproduction of the Algae. Vol. 1. (University Press: Cambridge).

Harper, J.T. and Saunders, G.W. (1998) A molecular systematic investigation of the Acrochaetiales (Florideophycidae, Rhodophyta) and related taxa based on nuclear small-subunit ribosomal DNA sequence data. Eur. J. Phycol 33: 221-229.

Isrealson, G. (1942) The Freshwater Florideae of Sweden. Studies on their taxonomy, ecology, and distribution. Sym. Bot. Ups. 6,1: 1-135.

Jao, C.C. (1941) Studies of the Freshwater Algae of China VIII. A preliminary account of the Chinese freshwater Rhodophyceae. Sinensia, 12: 245-289.

Leukart, P. and Knappe, J. (1995) Observations on Balbiania investiens (Rhodophyta) from two new localities in Germany and from laboratory culture. Nova Hedwigia 60: 527-532. 
Necchi, O. Jr., Sheath, R.G. and Cole, K.M. (1993a) Systematics of freshwater Audouinella (Acrochaetiaceae, Rhodophyta) in North America. 1. The reddish species. Arch. Hydrobiol., Suppl. Bd 98, Algological Studies 70: 11-28.

Necchi, O. Jr., Sheath, R.G. and Cole, K.M. (1993b) Systematics of freshwater Audouinella (Acrochaetiaceae, Rhodophyta) in North America. 2. The bluish species. Arch. Hydrobiol., Suppl. Bd 98, Algological Studies 71: 13-21.

Necchi, O. Jr. and Zucchi, M.R. (1995) Systematics and distribution of freshwater Audouinella (Acrochaetiaceae, Rhodophyta) in Brazil. Eur .J. Bot. 30:209-218.

Prescott, G. W. (1951). Algae of the Western Great Lakes Area, Exclusive of Desmids and Diatoms. (Cranbrook Institute of Science, Bulletin No. 31: Cranbrook Press, Michigan).

Sheath, R.G. and Müller, K.M. (1999). Systematic status and Phylogenetic Relationships of the Freshwater Genus Balbiania (Rhodophyta). J. Phycol. 35: 855-864.

Skinner, S. \& Entwisle, T.J. (2001). Non-marine algae of Australia: 1. Survey of colonial gelatinous blue-green macro-algae (Cyanobacteria). Telopea 9: 573-599.

Skuja, H. (1934) Untersuchungen über die Rhodophyceen des Süßwassers. Beih. Bot. Centralb. 52: 173-192.

Vis, M.L., Saunders, G.W., Sheath, R.G., Dunse, K. and Entwisle, T.J. (1998) Phylogeny of the Batrachospermales (Rhodophyta) inferred from rbcL and 18S Ribosomal DNA gene sequences. J. Phycol. 34: 341-350.

Woelkerling, W.J. (1983) The Audouinella (Acrochaetium-Rhodochorton) complex (Rhodophyta): present perspectives. Phycologia 22: 59-92.

Manuscript received 4 April 2001

Manuscript accepted 2 November 2001 